\title{
Author Correction: Concerted pulsatile and graded neural dynamics enables efficient chemotaxis in $C$. elegans
}

Eyal Itskovits (1), Rotem Ruach, Alexander Kazakov \& Alon Zaslaver

Correction to: Nature Communications https://doi.org/10.1038/s41467-018-05151-2, published online 20 July 2018.

The original version of this Article omitted from the author list the third author Alexander Kazakov who is from the "Edmond and Lily Safra Center for Brain Sciences, The Hebrew University of Jerusalem, Israel'. The following was added to the Author contributions: 'A. K. established the freely-behaving worm tracking system'. This has been corrected in both the PDF and HTML versions of the Article.

Published online: 22 October 2020

\begin{abstract}
(c) (1) Open Access This article is licensed under a Creative Commons Attribution 4.0 International License, which permits use, sharing, adaptation, distribution and reproduction in any medium or format, as long as you give appropriate credit to the original author(s) and the source, provide a link to the Creative Commons license, and indicate if changes were made. The images or other third party material in this article are included in the article's Creative Commons license, unless indicated otherwise in a credit line to the material. If material is not included in the article's Creative Commons license and your intended use is not permitted by statutory regulation or exceeds the permitted use, you will need to obtain permission directly from the copyright holder. To view a copy of this license, visit http://creativecommons.org/licenses/by/4.0/.
\end{abstract}

(๑) The Author(s) 2020 